\title{
Implementing quality assurance system for open and distance learning in three Asian open universities: Philippines, Indonesia and Pakistan
}

\author{
Aminudin Zuhairi
}

Universitas Terbuka, Tangerang Selatan, Indonesia

Maria Rowena Del Rosario Raymundo

Faculty of Education, University of the Philippines Open University, Los Banos, Philippines, and

Kamran Mir

Directorate of ICT, Allama Iqbal Open University, Islamabad, Pakistan

\begin{abstract}
Purpose-Quality assurance (QA) in open and distance learning (ODL) has always become universal concerns of stakeholders. The quality of ODL has been confronted with challenges in terms of the diversity of inputs, processes, the complex supply chain management of ODL and recent paradigm shift into online learning. Assuring the quality of ODL are daunting tasks at individual, institution and system levels. Completed before the beginning of the COVID-19 outbreak, this study aims to better understand the implementation of QA system in three Asian open universities (OUs), namely University of the Philippines Open University (UPOU), Universitas Terbuka (UT), Indonesia and Allama Iqbal Open University (AIOU), Pakistan.

Design/methodology/approach - A qualitative method was employed involving analysis of documents of the three Asian OUs and focus group discussions and interviews with management and staff. Data collected were then analyzed to draw conclusions and possible recommendations.

Findings - Findings of this study presented good practices, challenges and rooms for improvement of the QA system in the three Asian OUs. Focusing on students and stakeholders in their QA effort, this study has revealed that quality begins with inner self and is multidimensional. QA is principally viewed as continuous improvement, as mechanism and assessment and as effort at exceeding expectations of students and stakeholders. The recent challenge for QA is to embrace a delicate process of ODL transformation into online digital system. The recent COVID-19 outbreak has further implications and challenged QA implementation in ODL in higher education into the next level of complexity.
\end{abstract}

(C) Aminudin Zuhairi, Maria Rowena Del Rosario Raymundo and Kamran Mir. Published in Asian Association of Open Universities Journal. Published by Emerald Publishing Limited. This article is published under the Creative Commons Attribution (CC BY 4.0) licence. Anyone may reproduce, distribute, translate and create derivative works of this article (for both commercial and non-commercial purposes), subject to full attribution to the original publication and authors. The full terms of this licence may be seen at http://creativecommons.org/licences/by/4.0/legalcode

This paper is the outcome of a study on QA in ODL supported by the AAOU Exchange Fellowship at University of the Philippines Open University (UPOU) during the month of November 2019. The authors specifically thank the Chancellor and Vice Chancellor for Academic Affairs of UPOU for hosting the AAOU Fellowship 2019, the Vice-Chancellor of Allama Iqbal Open University (AIOU) Pakistan for including AIOU in the study, and the Rector of Universitas Terbuka (UT) Indonesia for the recommendation and permission to take up the prestigious AAOU Award. Further thanks go to QA Research Assistants of UPOU for their special effort in data collection for this research. More appreciations go to leaders, managers and staff members for the lively discussions and feedback and for sharing ideas on QA in ODL in the three Asian Open Universities.

Implementation of $\mathrm{QA}$ in ODL 
AAOUJ 15,3

Practical implications - This study revealed the diversities in how OUs met the societal needs of their respective stakeholders and addressed the challenges ahead for QA in ODL.

Originality/value - These findings were expected to enhance the understanding of the theory and practice of QA in ODL and to contribute to quality improvement of ODL programs.

Keywords Open and distance learning, Online learning, Quality assurance, Open universities

Paper type Research paper

\section{Introduction}

Quality has been a major importance for higher education (Inglis, 2005), and the provision of quality higher education is a major challenge to address by open universities (OUs) and open and distance learning (ODL) institutions. This study attempts to better understand the implementation of quality assurance (QA) system in three Asian OUs, namely University of the Philippines Open University (UPOU), Philippines; Universitas Terbuka (UT), Indonesia and Allama Iqbal Open University (AIOU), Pakistan. Quality has existed in these three OUs since their beginnings of operations, and QA system has been further implemented. As new QA methods emerge and ODL systems evolve, OUs also adapt to new ways of assuring quality to meet the expectations of students and the stakeholders. This research aims to reveal QA implementation in the three OUs in terms practices, challenges and rooms for improvement and learning lessons that may be relevant to the OUs and relevant ODL systems. Findings of this study are to present insights into exploring new ways of effectively implementing QA system in ODL. This study was conducted prior to the COVID-19 outbreak, and thus a section on the implications of COVID-19 pandemic on ODL directions has been added.

\section{Meaning of quality}

The meaning of quality has been much debated, and stakeholders, educational institutions and students may hold different conceptions of quality. "Quality is in the eye of the beholder" (Harvey and Green, 1993; Brockerhoff et al., 2015), and it will remain an important challenge for higher education. Quality is a relative concept as "it means different things to different people" (Harvey and Green, 1993). Harvey and Green's conceptualization of quality in higher education has been widely used in which quality is categorized into five discrete but interrelated ways of viewing quality as exceptional, as perfection (or consistency), as fitness for purpose, as value for money and as transformative (Harvey and Green, 1993). The true meaning of quality in higher education is not as simple as it has been generally perceived. Van Kemenade et al. (2008) define quality in terms of value systems and suggest four value systems on quality and quality management for analysis, namely: process control, continuous improvement, commitment and breakthrough. Within these value systems, process control relates to compliance to rules, procedures and standards and is relevant to the industrial management of distance education, and continuous improvement has been added to have no limit to the level of improvement to achieve (Van Kemenade et al., 2008).

Difficulties in defining the meaning of quality pose challenges in development of methods of assessing the quality, in which the quality assessment methodology need to meet the criteria for public accountability, academic credibility, practical feasibility and quality audit (Harvey et al., 1993). It may be unnecessary to have a universal definition of quality, as quality and QA may be culture context (Schindler et al., 2015), and that there seems to be no agreement on universal definition, model, and practices of QA in higher education (Ryan, 2015). Each institution may have their own definitions, models and practices that suit to their respective cultures and stakeholders' requirements. OUs and ODL institutions establish their own QA processes, follow accreditation systems and implement internal QA systems that suit the culture contexts and meet stakeholders' expectations of the respective countries. 
Quality teaching and learning or the pedagogical techniques to produce learning outcomes for students is one important educational goal to achieve in higher education. Achieving quality teaching and learning is a complex endeavor involving multiple dimensions, including design of curriculum and course content, learning contexts, use of feedback, assessment of learning outcomes, learning environments and student support services (Hénard and Roseveare, 2012). In an ODL system, a comprehensive and an integrated online student support system is mandatory to maintain the quality of open and distance learning (Mir, 2017; Mir et al., 2019). ODL requires more endeavors in terms of logistics, supply chain management and supporting activities, such as laboratories to support effective teaching and learning of science online at a distance (Kennepohl and Shaw, 2010). Quality teaching and learning a variety of subjects in ODL institutions may be difficult to define and standardize in terms of process, as different subjects may require different approaches to teaching and learning, pedagogical foundations and designs depending on students' needs, delivery and logistic requirements. Quality has been defined and understood from many different angles, that may have consequences on how QA policies and operational systems are to be implemented. Elken and Stensaker (2018) have conceived the idea of "quality work" in higher education and suggested multiple approaches to quality in higher education embracing the dimensions of management, work and quality.

\section{Quality assurance in open and distance learning}

QA in ODL has been a field of practice that has dominated educators and stakeholders during the past several decades. The meaning of quality has ramifications on the practice of QA in ODL, including massive open and online curses (MOOCs). The transformation of ODL into online learning has taken place as part of developments in the use of new technology in teaching and learning. Technology has enabled the emergence of online learning in higher education during the last decade of the past century (Anderson and Elloumi, 2004). Online learning continues to flourish with the introduction and widespread use of MOOCs by campus-based higher education institutions to reach wider audiences (Baturay, 2015).

Effort on QA in online learning has been strengthened through publication of guidelines (Uvalić-Trumbić and Daniel, 2013; Grifoll et al., 2010; Huertas et al., 2018). Research on QA for online higher education programs has been conducted identifying the system of indicators for the quality assessment for online higher education programs (Marciniak, 2018) and using PDPP (planning, development, process and product) evaluation model (Zhang and Cheng, 2012). Effective implementation of QA system in OUs, ODL and online learning system has been daunting tasks and shared responsibilities by the management, people, and stakeholders involved in ODL(Alfonso, 2015; Belawati and Zuhairi, 2007; Bibi et al., 2018; Jamandre, 2011; Jung et al., 2013).

Research findings on the development of QA in Asian ODL has revealed variations on the level of QA policy integration in the overall national QA in higher education policy, and these pose challenges for higher education institutions and governments to ensure quality graduates for the job market (Jung et al., 2011). Jung (2012) has further analyzed Asian learners' perception of ODL in terms of three domains, namely supportive domain (faculty supports, student supports, information and publicity), pedagogical domain (teaching and learning, course development, teaching and learning, interactive tasks, evaluation and assessment) and environmental domain (infrastructure, internal QA mechanism and institutional credibility). Benchmarking and assuring the quality of graduates for employability becomes priority of many higher education institutions and governments. QA concepts and implementations in ODL system have also evolved to respond to changing students' needs, technological developments and transformation into digital and online learning (Arinto, 2016; Vlachopoulos, 2016). It is worth noting the relevance of variations in 
AAOUJ 15,3

QA policy integration, transformation into online learning and methods to address these issues in the contexts of Philippines, Indonesia and Pakistan.

Quality is everyone's concern, and QA movement has encouraged educational organizations and governments to develop guidelines for use by higher education institutions. Organizations with stakes in ODL such as UNESCO, COL and AAOU have produced toolkits and guidelines to help members achieve their QA implementation (COL, 2009; AAOU, 2019). Stakeholders with interests in assuring QA of online learning also develop guidelines to quality in online learning for reference by interested parties (UvalićTrumbicand Daniel, 2013). Despite the effort, the integration of quality management system, accreditation system, internal assessment and external quality review has remained a challenge for many ODL institutions. There are specific matters to address in QA for ODL because of the specific characteristics of the ODL system (Stella and Gnanam, 2004).

QA in higher education can be analyzed at three different levels: individual, organizational and system levels (Brockerhoff et al., 2015). Analyses at individual and organizational levels can be more readily conducted, as it is generally under the supervision and monitoring of the leaders of the institution. Analyses at system level go further beyond individuals and the organization, may include outcomes that are difficult to assess and can be more complicated to evaluate, as it needs to involve external governance arrangements and efficiencies. Governments also refer to published QA frameworks as reference to establish their national QA systems for higher education.

Open universities have been under pressures to meet the students' and stakeholders' expectations on quality. A number of studies on QA in online learning and teaching have been conducted to address the issue of quality along with the changing higher education landscape as the results of the use of online technologies in teaching and learning (Kooi and Ping, 2012; Sembiring and Rahayu, 2019). A study in Malaysia has indicated the use of quality tools to improve student retention supporting process (Chuah and Lim, 2018). QA agencies have played increasingly important roles to ensure quality and public accountability of higher education programs (Zhang and Patil, 2017: Stensaker, 2018). Perceptions of quality on ODL varies from different stakeholders and students across different regions (Jung, 2012), and so diverse approaches to QA in ODL across Asia has been implemented (Jung et al., 2011). Various ODL systems have intensified their effort to integrate technology enhanced learning into their existing systems (Volungeviciene et al., 2014) and carefully addressed the issues of the convergence of open learning philosophies, distance education pedagogies and e-learning technologies (Arinto, 2016; Vlachopoulos, 2016).

\section{Quality assessment and accreditation in the three Asian open universities}

Quality assessment and accreditation in the three Asian OUs in Philippines, Indonesia and Pakistan have been implemented, and they share commonalities and differences due to diverse society needs and stakeholders' expectations. For Southeast Asia, at the regional ASEAN (Association of South East Asia Nations) level in which the Philippines and Indonesia are member countries, assuring the quality of higher education has become one of the common goals of governments through joint collaborative efforts. ASEAN-wide guiding principles on QA and recognition of competency certification system have been published to provide reference for implementation by ASEAN member states (ASEAN Secretariat, 2016). The ASEAN University Network has published a guideline for use by the member as well as other interested institutions (AUN, 2016). The 2006 ASEAN QA framework provides the basis for developing understanding for the recognition of competency certification systems, establishing guiding principles and protocols for developing processes for recognition of these systems and reviewing the state and development needs for QA among ASEAN member countries (ASEAN Secretariat, 2016). 
QA in higher education shares common principles in different countries (Al Tobi and Duque, 2015; Dotong and Laguador, 2015). For higher education in Philippines and Indonesia, QA in ODL may be viewed as continuous improvement process (Ruiz and Junio-Sabio, 2012; Tadjudin, 2001). In Indonesia, the Ministry of Education and Culture has continuously updated guideline for internal QA System for implementation by higher education institutions (Kemenistekdikti, 2018). The Philippines has had a long history of QA system and accreditation for higher education, starting in 1957 with the establishment of the country's first accrediting agency, the Philippine Accrediting Association of Schools, Colleges and Universities (Corpus, 2003). The Philippines government has continuously improved its QA system and has been moving towards the development of self-regulation policies, mechanisms and procedures (Ruiz and Junio-Sabio, 2012).

Indonesia has had a long history, large number of students, different types of public and private higher education institutions and a diverse system of higher education in terms of governance, access and quality (Logli, 2016). The national higher education system of Indonesia enrolls over $6.9 \mathrm{~m}$ students, and the system employs more than 275,000 lecturers and professors (Ahmad, 2018). These diverse groups and characteristics of higher education institutions in Indonesia pose specific challenges in terms of diversity in quality and ways to address them to ensure the Indonesian higher education system meets quality criteria and public expectations. The formal QA movement in Indonesian higher education has begun recently during the beginning of the 2000s with the publication of Guidelines for Internal QA System for implementation by public and private higher education institutions in Indonesia (Kemenristekdikti, 2018). QA system necessitates internal and external assessment, and higher education institutions need to ensure that quality criteria are met. An internal QA unit in each institution has been established to develop internal guidelines, standards and procedures for implementation within the institution, and mechanisms for audit are developed. Externally, higher education institutions need to assure that the products and services meet quality criteria set by its stakeholders. External assessment conducted by certification and accrediting agencies or external quality review agencies is important to ensure that the internal quality criteria meet certain level of benchmark to external quality criteria.

The Government of Pakistan through its Higher Education Commission has strong commitment to QA and enhancement of higher education through the publication of Quality Assurance Manual for Higher Education in Pakistan as reference for higher education system to implement QA system. Earlier, the Pakistan Quality Assurance Agency (QAA) was established in 2004 within the Commission of Higher Education "as a specialized body to introduce and encourage the development of quality culture in higher education". The Pakistan higher education system follows the guidelines and manuals of QA issued by the Pakistan Higher Education Commission (Batool and Qureshi, 2008). Quality higher education is a top priority for the Government of Pakistan to ensure quality education for the citizens (Usmani et al., 2012) through which the QAA established Quality Enhancement Cells within the higher education institutions to conduct self-assessment reports of academic programs (Usmani and Khatoon, 2016).

\section{Method of the study}

This study employed qualitative method involving analyses of documents, focus group discussion and interviews with management and staff. The documents for analysis include institutional documents, and other publications of UPOU, UT and AIOU. Focus group discussions and interviews with management and staff were conducted to have in-depth understanding and clarify matters. The authors spent one month at UPOU analyzing the documents, collecting data and having discussions and interviews with management and 
AAOUJ 15,3

302 staff. Further data collection activities were also conducted in UT and AIOU to ensure that recent information could be updated and latest development of the three institutions under study could be added.

This research aims to understand how QA systems are implemented in UPOU, UT and AIOU. The study focused on revealing practices, challenges and rooms for improvement in terms of QA implementation in the three Asian OUs. This study replicated the research methods of two previous comparative studies of various aspects of OUs in Sri Lanka, Taiwan and Indonesia, and thus some of the findings on particular aspects of this present study on UT, particularly on the characters and good practices of the institution, were adapted and updated from these previous two studies on supporting learners in ODL (Zuhairi et al., 2019) and on empowering lifelong learning (Zuhairi et al., 2020).

During this present study in UPOU in November 2019, the authors conducted interviews and focus group discussions on QA with senior administrators, managers, academic members of staff and QA support staff. Furthermore, individual authors also conducted interviews with management and staff of the respective institutions to get updates of recent developments of the three OUs under investigation. List of people consulted at UPOU through focus group discussion and interviews could be found in Appendix (See Appendix. List of people consulted at UPOU Philippines).

\section{Findings and discussion}

Findings of this study provided information about QA implementation and the potential directions of OPOU, UT and UT as modern OUs in providing quality ODL programs to students. Comparing OUs has been a difficult endeavor, as each institution has been designed distinctively by its stakeholders to address the specific needs of the respective societies. Yet there are common indicators that the three Asian OUs may be compared to provide insights on how they function as effective OUs accessible by large number of students in flexible manner.

The unique differences of the three Asian OUs were observed. Although each open university has been designed to serve their respective national clients, ODL system has also allowed the citizens of the respective countries living globally to have access to their ODL programs online. The three OUs have been made capable of accommodating everybody into the program, including those noncitizens. UPOU is predominantly intended to provide postgraduate programs at the master and doctoral levels, with fewer undergraduate programs. UT is a comprehensive open university offering diploma and degree at undergraduate and post-graduate levels, with most of the students studying for undergraduate degrees. As a comprehensive open university, AIOU offers undergraduate and post-graduate programs and even accommodates large number of students taking high-school certificates. Table 1 illustrates indicators of the three OUs in terms of date established, area served, language of instruction, client, faculty, programs offered, head office, regional offices and learning centers and QA system.

\section{Good practices of the three Asian open universities}

The three Asian OUs share common practices in serving their respective societies appropriately. As ODL pioneers in their respective countries, they transform themselves adapting to the new landscape of online digital learning. UPOU has jumped right from the beginning into becoming an open online university. UT and AIOU have diverse groups of students with different access to technology and thus accommodate both traditional distance students and online students. The three OUs are state institutions addressing the common challenge for quality flexible learning for their respective students and leading their roles as 


\begin{tabular}{|c|c|c|c|c|}
\hline Indicators & UPOU & UT* & AIOU & $\begin{array}{l}\text { Implementation } \\
\text { of QA in ODL }\end{array}$ \\
\hline Date established & 23 February 1995 & 4 September 1984 & 1 May 1974 & \\
\hline Area served & National and global & National and global & National and global & \\
\hline $\begin{array}{l}\text { Language of } \\
\text { instruction }\end{array}$ & English & Bahasa Indonesia, English & English, Urdu & \\
\hline Client & $\begin{array}{l}\text { Philippines and } \\
\text { everybody }\end{array}$ & Indonesians and everybody & \multirow{4}{*}{$\begin{array}{l}\text { Pakistanis and } \\
\text { everybody } \\
4 \\
200+ \\
15 \mathrm{PhD}+73 \text { Master }\end{array}$} & 303 \\
\hline \multirow{3}{*}{$\begin{array}{l}\text { Faculty } \\
\text { Study Programs } \\
\text { Post-graduate } \\
\text { programs }\end{array}$} & 3 & 4 & & \multirow{2}{*}{000} \\
\hline & 30 & 48 & & \\
\hline & $\begin{array}{l}2 \text { Doctoral + } 26 \text { Graduate } \\
\text { Diploma/ Master }\end{array}$ & 7 Master +2 Doctoral & & \multirow{9}{*}{$\begin{array}{r}\text { Table 1. } \\
\text { Institutional indicators } \\
\text { of three Asian open } \\
\text { universities }\end{array}$} \\
\hline $\begin{array}{l}\text { Undergraduate } \\
\text { programs }\end{array}$ & 3 & 29 & $100+$ & \\
\hline Courses & - & 1,257 & $2,000+$ & \\
\hline MOOCs & 100 & 23 & Data N/A & \\
\hline Head office & Los Banos & Tangerang Selatan & Islamabad & \\
\hline \multicolumn{2}{|l|}{$\begin{array}{l}\text { Regional offices/ } \\
\text { Learning centers }\end{array}$} & $39+1$ Overseas Student Center & $\begin{array}{l}48+1,100+\text { study } \\
\text { centers }\end{array}$ & \\
\hline \multirow[t]{2}{*}{ QA system } & Starting under UP & Internal Mechanism, ISO, & Following Higher & \\
\hline & $\begin{array}{l}\text { System, looking into } \\
\text { internal and external } \\
\text { assessment }\end{array}$ & $\begin{array}{l}\text { International Council for Open } \\
\text { and Distance Education (ICDE), } \\
\text { National Accreditation Board for } \\
\text { Higher Education (BAN-PT) }\end{array}$ & $\begin{array}{l}\text { Education Commission } \\
\text { (HEC) QA Guidelines }\end{array}$ & \\
\hline \multicolumn{4}{|c|}{ Source(s): *Taken and adapted from (UT, 2019a; UT, 2020; Zuhairi, 2019) } & \\
\hline
\end{tabular}

open, distance and online learning nationally. Table 2 indicates good practices of the three Asian OUs in terms of institution character and responsibility, core value, programs offered, missions, funding and tuition fees, and national roles.

\section{Challenges of the three Asian Open Universities}

The three OUs share common challenges, particularly pressures to accommodate even larger number of ODL students. Integrating online learning and the use of new technology offer greater flexibility for OUs, but there are constraints for those students that have limited access to new technology and online services. The use of new technology confronts OUs to train staff and students and familiarize them with the technology to facilitate learning. There are also the issues of openness and lifelong learning. How open an OU depends very much on the government policies and the institution capabilities to serve various kinds of students. Integrating learning and teaching online is a further challenge because of the different groups of students the OUs serve and the academic staff readiness with the new ways of teaching and learning online. Table 3 illustrates the challenges of three Asian OUs in terms of student numbers, integrating online learning, access to services, new technology, staff training, academic staff workload, admission policy and duration of study.

\section{Rooms for improvement for the three Asian open universities}

There are rooms for improvement relevant to individual institutions under study. Each of the OUs have specific strategies in providing student support due to the differences in student characteristics. Stakeholders generally have high expectations in the capability of OUs to accommodate large number students in higher education. Table 4 indicates rooms for improvement for three Asian OUs in key areas of student support, participation in higher education, lifelong learning and partnerships. 


\section{AAOUJ 15,3}

304

\begin{tabular}{ll}
\hline Aspects & UPOU \\
\hline $\begin{array}{l}\text { Institution } \\
\text { character }\end{array}$ & Fully online ODL institution \\
$\begin{array}{l}\text { Institution } \\
\text { responsibility }\end{array}$ & $\begin{array}{l}\text { Provide access to quality } \\
\text { higher education through } \\
\text { innovative methods of } \\
\text { teaching and learning }\end{array}$
\end{tabular}

Core value

Programs offered

Missions

Funding and tuition fees

Table 2.

National roles

Good practice of the three Asian Open Universities
Honor, Excellence, Equity, Efficiency, Humanism Predominantly postgraduate open university with 30 post-graduate programs at diploma, master and doctoral levels, and several undergraduate programs in 3 Faculties

Provide wider access to quality higher education to the highest standards of academic excellence, guarantee academic freedom, and encourage social responsibility and nationalistic commitment among its faculty, staff and students

Rely on government funding with students pay low fees; free tuition for undergraduates; single-level fee structure for postgraduate programs Pioneering ODL institution in the Philippines
UT* AIOU

Open university transforming to be a cyber university

Provide academic services based on partnerships using resources of partner institutions: academic, human, infrastructure, facilities

Making quality higher education open to all A wide range of programs with very large number of students at all levels in 4

Faculties and The

Graduate Program, and a total of 40 Study Programs at bachelor, master, and doctoral levels

Reach out high school graduates, those living in remote and rural areas, and everybody else

ODL university

Provide educational facilities to people who cannot leave their homes and jobs

Education for All

A comprehensive university with a wide range of programs across different fields in 4 Faculties

\section{To provide quality} education to the masses and to those who cannot leave their homes and jobs

Rely on student fees and government funding, manage services effectively, and known as the lowest fees among state universities

Pioneering cyber university and the only open university
Rely on student fees and government funding, fee structure level wise but it is quite low as compared with regular face to face institutions

The biggest university in the country with over 1.2 million students

Source(s): *Adapted and updated from Zuhairi et al. (2020); Zuhairi et al. (2019)

Good practices in $Q A$ system in the three Asian open universities

OUs have the natural characters of openness, flexibility and capacity to reach wider audience through open, distance and online learning. QA has been an important instrument to improve the quality of ODL with large number of students. An earlier study on QA in Asian ODL system has revealed variability in terms of the level of QA policy integration in the overall national QA in higher education policy framework as well as QA purpose, policy frameworks, methods and instruments, despite obvious commonalities that underpin their QA efforts (Jung et al., 2011). The QA movement in higher education beginning in the 1990s has had constructive effects on OUs, including those in UPOU, UT and AIOU. It was during those times that many OUs started to formally address the challenge for quality and establish QA system for implementation to meet stakeholders' expectations.

UPOU was established in 1995 with the purpose to democratize access to quality higher education through ODL, being one of seven universities and an autonomous college of 


\begin{tabular}{|c|c|c|c|c|}
\hline Aspects & UPOU & $\mathrm{UT}^{*}$ & AIOU & \\
\hline $\begin{array}{l}\text { Student } \\
\text { numbers }\end{array}$ & $\begin{array}{l}\text { Accommodate greater } \\
\text { number of post-graduate } \\
\text { and undergraduate } \\
\text { students }\end{array}$ & $\begin{array}{l}\text { Serve more distributed and } \\
\text { very large number of students } \\
\text { with different needs and } \\
\text { conditions }\end{array}$ & $\begin{array}{l}\text { A very large number of } \\
\text { students from various } \\
\text { backgrounds across the } \\
\text { country, over } 600,000 \text { per } \\
\text { semester }\end{array}$ & \\
\hline \multirow{2}{*}{$\begin{array}{l}\text { Integrating } \\
\text { online } \\
\text { learning }\end{array}$} & \multirow{2}{*}{$\begin{array}{l}\text { Open cyber university, } \\
\text { integrating teaching and } \\
\text { learning and assessment }\end{array}$} & \multirow{2}{*}{$\begin{array}{l}\text { Transforming into online and } \\
\text { cyber university education } \\
\text { and competition among online } \\
\text { learning system }\end{array}$} & \multirow{2}{*}{$\begin{array}{l}\text { Digital transformation is in } \\
\text { process, top down approach is } \\
\text { being used to convert offline } \\
\text { students to online learning }\end{array}$} & 305 \\
\hline & & & & \\
\hline $\begin{array}{l}\text { Access to } \\
\text { services }\end{array}$ & $\begin{array}{l}\text { Incorporating universal } \\
\text { accessibility in its } \\
\text { operations }\end{array}$ & $\begin{array}{l}\text { Improved services to diverse } \\
\text { groups of students with } \\
\text { different needs and access to } \\
\text { various mode of services }\end{array}$ & $\begin{array}{l}\text { Provide access to the female } \\
\text { students and mass education, } \\
\text { reach out to the remotest areas }\end{array}$ & \\
\hline $\begin{array}{l}\text { New } \\
\text { technology }\end{array}$ & $\begin{array}{l}\text { Use of new technology, } \\
\text { being a cyber open } \\
\text { university }\end{array}$ & $\begin{array}{l}\text { Incorporating more uses of } \\
\text { new technologies to enrich } \\
\text { learning experience of } \\
\text { students, and in management }\end{array}$ & $\begin{array}{l}\text { Harnessmodern information } \\
\text { technology; digital literacy; } \\
\text { Internet and accessibility }\end{array}$ & \\
\hline Staff training & $\begin{array}{l}\text { Continuously train and } \\
\text { retrain staff on uses of } \\
\text { new technology }\end{array}$ & $\begin{array}{l}\text { Enhance staff training in new } \\
\text { technology for online } \\
\text { learning, OER and MOOCs }\end{array}$ & $\begin{array}{l}\text { Enhance staff training in new } \\
\text { technology }\end{array}$ & \\
\hline $\begin{array}{l}\text { Academic } \\
\text { staff } \\
\text { workload }\end{array}$ & $\begin{array}{l}\text { Fewer numbers of } \\
\text { academic staff; manage } \\
\text { workload to ensure } \\
\text { quality service }\end{array}$ & $\begin{array}{l}\text { Number of academic staff and } \\
\text { enhance academic staff } \\
\text { activities }\end{array}$ & $\begin{array}{l}\text { Ensure staff workload meet } \\
\text { criteria for quality service }\end{array}$ & \\
\hline $\begin{array}{l}\text { Admission } \\
\text { policy }\end{array}$ & $\begin{array}{l}\text { Open merit with selection } \\
\text { criteria and tests }\end{array}$ & $\begin{array}{l}\text { Open admission to all, } \\
\text { including those without high- } \\
\text { school certificates for } \\
\text { undergraduate courses, and } \\
\text { selection and tests for post- } \\
\text { graduate courses }\end{array}$ & $\begin{array}{l}\text { Open admissions for school } \\
\text { level courses, for most } \\
\text { undergraduate courses, and } \\
\text { open merit with selection } \\
\text { criteria and/or test/interview } \\
\text { for post-graduate level courses }\end{array}$ & \\
\hline $\begin{array}{l}\text { Duration of } \\
\text { study }\end{array}$ & $\begin{array}{l}\text { Policy on limit of } \\
\text { duration of study }\end{array}$ & $\begin{array}{l}\text { Lifelong learning, no dropout, } \\
\text { accreditation as a challenge }\end{array}$ & $\begin{array}{l}\text { Policy as per Higher } \\
\text { Education Commission }\end{array}$ & $\begin{array}{r}\text { Challenges of the three } \\
\text { Asian open }\end{array}$ \\
\hline \multicolumn{4}{|c|}{ Source(s): *Adapted and updated from Zuhairi et al. (2020); Zuhairi et al. (2019) } & \\
\hline
\end{tabular}

University of the Philippines (UP) system offering mostly post-graduate and a few undergraduate programs in social sciences and applied disciplines (Arinto, 2016). UPOU is one of the pioneers in open and distance e-learning as an innovative approach for delivering effective ODL to anyone in flexible manner using the digital technologies along with other forms of learning materials and support system (Oruga and Bagos, 2018). QA mechanism has existed in UPOU right from the beginning, and QA implementation has recently been strengthened involving external assessment internationally.

For UT, as the only state open university established in 1984, it has since consistently followed the rules, guidelines and procedures set by its parent Ministries of Education and Culture and of Finance to offer study programs to its ODL students. A systematic approach to QA in UT formally began in 2001 with the establishment of a QA Committee, and then followed in 2003 by the establishment of a QA Center, a unit dedicated to managing the implementation of a comprehensive QA system. UT began to adopt the Asian Association of Open Universities (AAOU) QA Framework 2001 as quality policies for implementation. The UT core activities, products and services were defined in terms of quality standards to be met. Standardized procedures were documented for implementation in relevant units by managers and persons in charge. QA is a continuous improvement process, and it necessitates transformation of the people within the institution in terms of quality culture and 


\begin{tabular}{|c|c|c|c|c|}
\hline \multirow{3}{*}{$\begin{array}{l}\text { AAOUJ } \\
15,3\end{array}$} & \\
\hline & Aspects & UPOU & UT & $\mathrm{AIOU}$ \\
\hline & Student support & $\begin{array}{l}\text { Provide services in } \\
\text { different modes }\end{array}$ & $\begin{array}{l}\text { Continuously improve the } \\
\text { quality of online learning } \\
\text { support }\end{array}$ & $\begin{array}{l}\text { Promote the use of } \\
\text { online learning to } \\
\text { students and staff }\end{array}$ \\
\hline \multirow[t]{2}{*}{306} & $\begin{array}{l}\text { Participation in } \\
\text { higher education }\end{array}$ & $\begin{array}{l}\text { Expand for opportunities } \\
\text { through open admissions }\end{array}$ & $\begin{array}{l}\text { Accommodate more students } \\
\text { and offer a wide range of } \\
\text { programs, including those for }\end{array}$ & $\begin{array}{l}\text { Increase higher } \\
\text { participation rates in } \\
\text { higher education }\end{array}$ \\
\hline & Lifelong learning & $\begin{array}{l}\text { Offering lifelong learning } \\
\text { courses beyond degrees } \\
\text { and diplomas }\end{array}$ & $\begin{array}{l}\text { doctoral levels } \\
\text { Strengthen lifelong learning } \\
\text { courses }\end{array}$ & $\begin{array}{l}\text { Continuous } \\
\text { improvement in lifelong } \\
\text { learning programs }\end{array}$ \\
\hline $\begin{array}{l}\text { Table } 4 . \\
\text { Rooms for } \\
\text { improvement of } \\
\text { institutions }\end{array}$ & Partnerships & $\begin{array}{l}\text { Consider partnerships } \\
\text { with capacity to } \\
\text { accommodate larger } \\
\text { number of students }\end{array}$ & $\begin{array}{l}\text { Strengthen partnerships and } \\
\text { establish core academic } \\
\text { infrastructure and facilities in } \\
\text { Head Office and selected } \\
\text { Regional Offices to support } \\
\text { learning }\end{array}$ & $\begin{array}{l}\text { Strengthen } \\
\text { partnerships for quality } \\
\text { improvement of ODL } \\
\text { services }\end{array}$ \\
\hline
\end{tabular}

commitment to QA (Belawati and Zuhairi, 2007). The UT has been challenged to transform itself and adapt to the new landscape of ODL, adopting online approach to teaching and learning in line with advances in the use of information and communication technology (Darojat, 2018).

UT is a pioneering ODL institution, serving ODL students using blended online learning. Many students opt for the face-to-face tutorial support provided by the UT, and there has been increasingly more students prefer online tutorial support that provides greater flexibility on the parts of the students. Implementing QA system in UT is a formidable task because of the different groups of students to serve and the geographical coverage of the students. Systematic approach to QA has since been implemented involving both internal and external assessment. The ISO 9001 certification has been implemented since 2005 for the quality management system of its industrial management processes, and the ISO 27001 for information technology security management has recently been attempted for implementation and certification. Accreditation of study programs and the institution have been conducted by the National Accreditation Board for Higher Education (BAN-PT). The International Council for Open and Distance Education (ICDE) has further conducted quality reviews every 3-5 years since 2005 to ensure that the UT practice of ODL meets international standards.

Established in 1974, AIOU has been the pioneer in nonformal and ODL in Pakistan, offering programs at both undergraduate and post-graduate levels as well as secondary and high school certificates for adult learners (Iqbal and Ahmad, 2010). QA is an important concern of the institution to ensure the provision of quality education for the people of Pakistan. AIOU has important roles in empowering lifelong learning among Pakistani citizens and ensuring access to quality higher education among high school graduates and adult learners.

The three Asian OUs share common good practices in QA system, although each OU may have referred to different framework and address to the respective need of the stakeholders. QA has been implemented with great care and serious considerations, involving both internal and external quality reviews. Table 5 illustrates good practices in QA system implemented in the three Asian OUs covering their internal mechanism, QA framework and mechanism, internal and external assessment, accreditation and international quality reviews. 


\begin{tabular}{|c|c|c|c|c|}
\hline Aspects & UPOU & UT & $\mathrm{AIOU}$ & \\
\hline QA system & $\begin{array}{l}\text { UP system formalized its QA } \\
\text { system through the } \\
\text { institutionalization of the UP } \\
\text { Academic Assessment and } \\
\text { Development System (UP } \\
\text { AADS) in Dec 2018, } \\
\text { involving internal } \\
\text { assessment and external } \\
\text { reviews }\end{array}$ & $\begin{array}{l}\text { A comprehensive QA } \\
\text { system implemented since } \\
2001 \text { with internal } \\
\text { assessment and external } \\
\text { reviews, accreditation and } \\
\text { certification }\end{array}$ & $\begin{array}{l}\text { Quality Enhancement Cell } \\
\text { since 2007; Quality } \\
\text { Assurance Agency (QAA) } \\
\text { of HEC; Commonwealth } \\
\text { of Learning Review and } \\
\text { Improvement Model } \\
\text { (COL-RIM) in } 2013\end{array}$ & 307 \\
\hline QA center & $\begin{array}{l}\text { QA officer person in charge } \\
\text { and focal persons introduced }\end{array}$ & $\begin{array}{l}\text { QA Center established since } \\
2003\end{array}$ & QA person in charge & \\
\hline QA framework & $\begin{array}{l}\text { ASEAN University Network } \\
\text { (AUN) QA framework }\end{array}$ & $\begin{array}{l}\text { AAOU QA framework since } \\
2001\end{array}$ & $\begin{array}{l}\text { Quality enhancement, QA } \\
\text { policies and programs by } \\
\text { the Higher Education } \\
\text { Commission (HEC) and } \\
\text { COL-RIM }\end{array}$ & \\
\hline QA mechanism & $\begin{array}{l}\text { Internal and external } \\
\text { reviews }\end{array}$ & $\begin{array}{l}\text { Internal and external } \\
\text { assessment }\end{array}$ & Internal and external & \\
\hline $\begin{array}{l}\text { Internal } \\
\text { assessment }\end{array}$ & $\begin{array}{l}\text { iAADS (Internal Academic } \\
\text { Assessment and } \\
\text { Development System) } \\
\text { originally developed by the } \\
\text { UP system in 2000, expanded } \\
\text { to iAADS + }\end{array}$ & $\begin{array}{l}\text { Internal audit every 6- } \\
12 \text { months for ISO }\end{array}$ & $\begin{array}{l}\text { Internal mechanism for } \\
\text { assessment }\end{array}$ & \\
\hline $\begin{array}{l}\text { External } \\
\text { assessment }\end{array}$ & $\begin{array}{l}\text { (1) Introduced } \\
\text { (2) Academic reviews } \\
\text { externally }\end{array}$ & $\begin{array}{ll}\text { (1) } & \text { ISO, BAN-PT, ICDE } \\
\text { (2) } & \text { ISO 9001 quality } \\
\text { management system } \\
\text { and ISO 27001 } \\
\text { information security } \\
\text { management system } \\
\text { every year review, and } \\
\text { three years } \\
\text { certification }\end{array}$ & $\begin{array}{l}\text { (1) HEC and COL RIM } \\
\text { (2) Academic reviews } \\
\text { externally }\end{array}$ & \\
\hline $\begin{array}{l}\text { External } \\
\text { assessment } \\
\text { nationally }\end{array}$ & $\begin{array}{l}\text { Meeting stakeholders' } \\
\text { expectations for external } \\
\text { reviews }\end{array}$ & $\begin{array}{l}\text { Study Program and } \\
\text { Institution Accreditation by } \\
\text { National Accreditation } \\
\text { Board for Higher Education } \\
\text { (BAN-PT) every three years }\end{array}$ & HEC program level & \\
\hline $\begin{array}{l}\text { External } \\
\text { assessment } \\
\text { internationally }\end{array}$ & $\begin{array}{l}\text { Quality reviews by ASEAN } \\
\text { University Network (AUN) }\end{array}$ & $\begin{array}{l}\text { Quality reviews by } \\
\text { International Council for } \\
\text { Open and Distance } \\
\text { Education (ICDE) }\end{array}$ & $\begin{array}{l}\text { Being carefully } \\
\text { considered }\end{array}$ & $\begin{array}{r}\text { Table } 5 . \\
\text { Good practices in QA } \\
\text { system }\end{array}$ \\
\hline
\end{tabular}

\section{Challenges in $Q A$ system in the three Asian open universities}

The three OU has taken quality assessment seriously. For UPOU, external quality reviews have been introduced recently. External assessment nationally is implemented to ensure that UPOU programs and courses meet stakeholders' expectations, while external assessment internationally has been conducted through quality reviews by ASEAN University Network (AUN). For UT, QA is a delicate process with the internal quality audit functioning to establish awareness, good attitudes and confidence in QA and to ensure that people work in compliance to guidelines and procedures. As a systematic continuous improvement effort, QA aims to develop quality work culture among people within the institution. External quality assessment aims to ensure public confidence of the QA system. At AIOU, the QA 
AAOUJ 15,3

\section{8}

Framework developed by the Commonwealth of Learning (COL) has been adopted with external assessment conducted by the Higher Education Commission (HEC). External academic reviews at national level have been conducted at program level by HEC. For AIOU, QA has involved the internal mechanism and the external benchmark and assessment by the Higher Education Commission.

The three Asian OUs have consistently implemented their respective QA system and addressed their challenges in different stages of QA development. Both UPOU and AIOU share common challenges in QA system, while UT has started QA earlier needs to strengthen its QA system to add values to the institution. Table 6 illustrates the challenges in QA implementation in terms of system, shared responsibilities, values, work culture, compliance and internal and external assessment. Quality assessment is an important component of any QA system, as it informs the institution and stakeholders the quality level achieved referring to certain criteria and benchmark. Internal assessment is important as feedback for continuous improvement and as a tool to appreciate effort on QA by the institution to its dedicated people implementing the system. External assessment using commonly accepted benchmark and external quality criteria is important to ensure public confidence. Table 6 illustrates challenges in QA system in terms of shared responsibilities, quality values and work culture, compliance and internal and external assessment.

\section{Rooms for improvement in QA system for the three Asian open universities}

The three Asian open universities share common rooms for improvement in QA system, despite the fact each of OUs has their own historical origins and paths for development. There are two major areas for improvement that the three Asian OUs share, namely shifting from distance to online learning QA system and from audit to analytics-based QA system. These findings confirm the importance of QA as priorities of the three Asian OUs. Table 7 presents rooms for improvement in QA system in terms of shifts from distance to online learning and from audit-based to analytics-based QA system.

\section{Implications of the post COVID-19 pandemic on QA implementation in ODL}

The study was completed just prior to the outbreak of theCOVID-19 pandemic, that have since brought about significant consequences on higher education and ODL systems

\begin{tabular}{|c|c|c|}
\hline Aspects & UPOU and AIOU & UT \\
\hline QA system & $\begin{array}{l}\text { Establish QA system for continuous } \\
\text { improvement involving internal } \\
\text { mechanism with internal and external } \\
\text { assessment }\end{array}$ & $\begin{array}{l}\text { Effective QA system for continuous } \\
\text { improvement of ODL programs involving } \\
\text { internal mechanism and with internal } \\
\text { assessment and external reviews by } \\
\text { various quality and higher education } \\
\text { authorities }\end{array}$ \\
\hline $\begin{array}{l}\text { QA as shared } \\
\text { responsibilities }\end{array}$ & $\begin{array}{l}\text { Develop awareness and ensure quality as } \\
\text { shared responsibilities }\end{array}$ & Ensure quality as shared responsibilities \\
\hline Quality values & Develop awareness of quality values & $\begin{array}{l}\text { Quality enhancement to ensure quality } \\
\text { work culture }\end{array}$ \\
\hline $\begin{array}{l}\text { Quality work } \\
\text { culture }\end{array}$ & $\begin{array}{l}\text { Develop quality-based work ethics and } \\
\text { values }\end{array}$ & $\begin{array}{l}\text { Develop quality-based work ethics and } \\
\text { values }\end{array}$ \\
\hline Compliance & Awareness training and retraining & Awareness training and retraining \\
\hline $\begin{array}{l}\text { Internal } \\
\text { assessment }\end{array}$ & $\begin{array}{l}\text { Begin start internal and self-assessment } \\
\text { for quality improvement }\end{array}$ & $\begin{array}{l}\text { Effective internal audit for effective } \\
\text { preventive actions }\end{array}$ \\
\hline $\begin{array}{l}\text { External } \\
\text { assessment }\end{array}$ & Begin to involve external assessment & $\begin{array}{l}\text { Effective reporting for self-assessment } \\
\text { and follow up of external assessment }\end{array}$ \\
\hline
\end{tabular}

Table 6.

Challenges in $\mathrm{QA}$ system
QA as shared responsibilities Quality values

Compliance assessment assessment shared responsibilities

Develop awareness of quality values values

Awareness training and retraining for quality improvement

Begin to involve external assessment
Effective QA system for continuous improvement of ODL programs involving external various quality and higher education authorities

Quality enhancement to ensure quality work culture values

Awareness training and retraining preventive actions and follow up of external assessment 
worldwide, including the three open universities under study. The COVID-19 pandemic has grown quickly to affect global operations of higher education and has called for the need for the deployment of emergency e-learning and the consequences for the securitization of higher education (Murphy, 2020). Stakeholders and organizations have been quick to address the issue of education affected by the COVID-19 pandemic through publications of policy ideas, guidelines, resource sharing initiatives, sharing of practices and action plans to respond to the on-going crisis (UNESCO, 2020a, b; World Bank, 2020, 2020a; OECD, 2020; IAU, 2020; Belawati and Nizam, 2020). These resources have helped higher education institutions to respond appropriately to the emergency necessities for e-learning implementation worldwide. These sudden transformations into online learning may have serious consequences on the quality assurance of higher education and ODL system that needs to be addressed carefully.

As earlier stated by Volungeviciene et al. (2014), OUs world worldwide vary in terms of the level technology-enhanced learning integration into the organization. The post COVID-19 experience may have different implications on OUs in different ways. The University of the Philippines (UP) system is a large multi-campus university system, first established in 1908, with seven campus-based universities in Diliman, Los Baños, Manila, Visayas, Mindanao, Baguio, Cebu and satellite campuses across the country and the UPOU headquartered in Los Baños (University of the Philippines, 2020). UPOU is already an open online university, and thus all students already use online learning support and services. UPOU should be able share good practices in online learning with the campus-based UP system. The COVID-19 pandemic has significant implications on higher education in the Philippines, including the UP system, pushing the campus-based system into applying remote learning, modular courses, MOOCs, televised courses and new technology (Llaneta, 2019). The UPOU experience in online learning should benefit the UP system in addressing its post-COVID19 higher education practice.

During the pre-COVID-19 pandemic, both UT and AIOU have gone through the continuous progress of transformation into online learning, with constantly increasing number of students using their online learning services. For UT, less than one-half of its student population uses online learning support, and for AIOU the proportion of students using online learning support has even been smaller. During COVID-19, AIOU introduced the concept of end term assessment (ETA), a kind of open-book exam to be performed at homes, as an alternate of final examination which was being held physically in examination halls before COVID-19. The workshop component of all teacher training and post-graduate programs of more than 100,000 students is being conducted online through virtual classroom environment and the AAGHI Learning Management System (LMS) in synchronous mode. All these systems are being managed and hosted by AIOU. The COVID-19 experience may highly likely drive both OUs and relevant higher education institutions to accelerate their online learning transformation processes that benefit the institutions and their students.

\begin{tabular}{ll}
\hline Aspects & UPOU, UT, and AIOU \\
\hline $\begin{array}{l}\text { Shift from distance to online } \\
\text { learning QA system }\end{array}$ & (1) $\begin{array}{l}\text { UPOU already a cyber online open university and has been } \\
\text { challenged in terms of continuous improvement in online learning }\end{array}$ \\
(2) Common rooms for improvement for AIOU and UT in open, distance \\
and transforming into quality online learning \\
based QA system
\end{tabular}

Table 7.

Rooms for improvement in QA system 
AAOUJ 15,3

310

The COVID-19 pandemic has prompted UT and AIOU to take actions adapting many of its academic services such as learning support and examination, as well as administrative services and quality audit activities, shifting from the face-to-face to mediated or web-based activities. Take UT as an example, during the COVID-19 pandemic the face-to-face tutorial services have been replaced with the web-based tutorials. Similarly, the paper-based semester examinations have been replaced with assignments or online examinations. These policy changes were to be communicated speedily with all students and staff. These changes in modes of services had to be understood precisely by the management and all staff in regional offices, as well as students and tutors in various regions. New orientations on these changes in the teaching, examination and assignment requirements were to be conveyed to the students and tutors timely to ensure common understanding among themselves.

The COVID-19 pandemic has had significant consequences on face-to-face higher education institutions and OUs. Campus-based universities need to adjust to the new normal for adopting e-learning methods to replace their traditional classroom teaching and learning. For Indonesia, higher education institutions have undergone sweeping digital transformation through adoption of online learning and new technology to replace the traditional face-to-face mode of learning in the light of the COVID-19 pandemic, and just within less than a month $98 \%$ of 4,621 Indonesian higher education institutions have suddenly gone online in response to the COVID-19 disruption (Belawati and Nizam, 2020; Nizam, 2020). These phenomena of campus-based universities transforming into online learning are also taking place in Philippines, Pakistan and virtually in every country worldwide in reaction to the COVID-19 (UNESCO, 2020a, b). Many campus-based universities have been involved in offering MOOCs, and they may have developed their necessities to improve and expand their distance learning capabilities along with its MOOCs. These post-COVID-19 technological transformations need to take various consideration perspectives related to digital literacy, pedagogy, digital learning materials, learning interactions, technology and assessment of learning (Belawati and Nizam, 2020).

The post-COVID-19 pandemic confronts specific challenges in the implementation of QA in ODL. Educational organizations and stakeholders have further published specific guidelines on facilitating flexible learning and ensuring the quality of its provision to address the challenge of education during COVID-19 pandemic (Huang et al., 2020a, b). For many higher education institutions and OUs, the COVID-19 pandemic has taught tough lessons to modernize and move forward even faster to become more technologically enhanced open and online universities able to reach various groups of students. For governments, they need to work out on policies that enable improved access through the development of open online learning policies that benefit their citizens. The OU and ODL systems historically have been established by their founders based on careful considerations on quality, access, equality and flexibility to ensure public trust and credibility. These principles have been continuously nurtured to ensure sustainability and ability to adapt to disruptions and address future challenges.

\section{Conclusion}

Significant effort has been put forth for implementing QA at UPOU, UT and AIOU. Findings of this study revealed the three OUs in terms of achievement, lessons and future directions. These findings would be helpful in identifying and charting the potential future action plans for continuous improvement in the individual OUs and their respective QA systems. These findings may also be of interest as reference by other OUs and ODL systems.

The three Asian OUs have their own achievements worth respecting.QA implementation has been a dedicated effort in the three Asian OUs, with seriousness of purpose, careful supervision, audits and involving management and staff to invest significant resources for 
the effort. Commitment to QA implementation has been a great start with the good spirit for continuous improvement. Management and staff work together as a team to ensure that the institution's vision, missions and goals be achieved through shared responsibilities. The three Asian OUs have developed an internal mechanism for QA, involving internal assessment as well as external assessment by the agencies responsible for ensuring quality higher education in the respective countries. UT has gone further in external quality assessment through the ISO 9001, 21001 and ISO 27001 certifications, study program and institution accreditations by the BAN-PT and reviews by a panel of quality experts of the ICDE. The missions and goals of OUs are constantly aligned to satisfy the needs of students and stakeholders. One important common value shared by the three OUs is that QA has been acknowledged as a shared responsibility by all.

Some lessons may be learnt from the three Asian OUs. Effective implementation needs significant effort, resource commitments and internalization among management and staff to develop quality awareness and values for continuous improvement. Human resources need to be trained and retrained to comply guidelines and procedures to provide services at the highest quality level. Internal and external assessments need significant effort and time to prepare and different external assessment conducted by different bodies require specific preparation, as each of the external bodies may have different information requirements and criteria for quality assessment. External bodies come at different time with different emphases on the aspects of quality under assessment. These external assessment regimes may cause lots of pressures to management as staff, as they consume significant amount of time and energy for preparation and follow up of their findings. All management and staff need to be directed towards the achievement of the goals of OUs as quality ODL providers in higher education.

There are possible future directions worth considering by the three Asian OUs that may also be relevant to other OUs, particularly in the use of technology in ODL. OUs worldwide, including the three Asian OUs, have committed investment and resources to transform themselves into modern OUs, which provide services on digital platform. Information technology has become the backbone and nerve center to provide both administrative and academic services to students with respects to their learning needs and styles. OUs are challenged to address these changing landscapes in the ODL provision on massive scales and global scope. New technology has allowed higher education institutions of all kinds, campusbased and open universities, to offer blended and online learning courses of high quality and relevance to society needs. Significant changes in the way higher education institutions offer high-quality programs on-campus and online are challenging OUs to adapt to the changing landscapes of online learning environment.

The Asian ODL systems have gone through phenomenal expansion during the past five decades, and there has since been growing public demand for ODL quality and accountability (Jung et al., 2011).There are common characters in implementing QA system in the three Asian OUs in which QA system is a viewed as shared responsibilities adopted by their leaders, respected by both management and staff, and implemented by all people. Such great values have been internalized through a long process of trials and continuous improvement. Common beliefs are established and continuously refined to ensure sustainability. This study of three Asian OUs comes to final conclusions on the characters of their QA systems as illustrated in Figure 1.

Quality ODL system focuses on effectively meeting the needs of ODL students and stakeholders. The COVID-19 pandemic has compelled ODL system to be able to ensure sustainability though continuous adaptation and innovation (World Bank, 2020a). Quality ODL puts students and their stakeholders first at the center of its QA and improvement effort, along with adaptability to respond to disruption, such as COVID-19. ODL institutions work closely with stakeholders to identify their needs and then develop programs and courses that 


\section{AAOUJ 15,3}

\section{2}

Figure 1.

The characters of QA systems of three Asian open universities

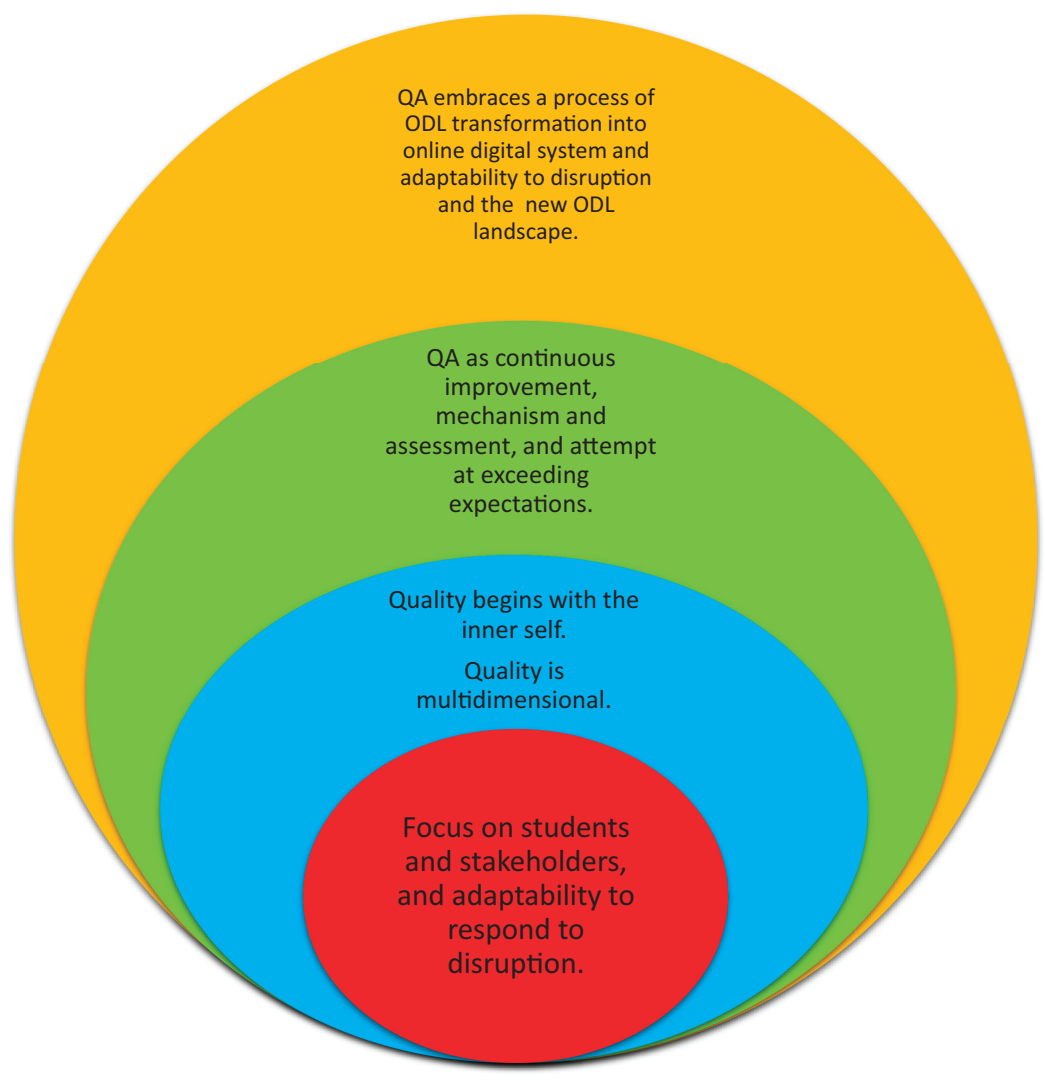

are relevant to their needs and those of potential employers. ODL institutions keep assessing themselves the quality level which they are in, design action plans on how to improve them and then systematically implement those plans to improve quality. ODL institutions also continuously ask their students on their levels of satisfactions, and then decide which areas of services need further improvement and which areas of their strengths that they continue to maintain. Conclusions are made and elaborated to better understand the characters of the QA systems of the three Asian OUs.

First, the value "quality begins with inner self" seems to be universal merits implemented in OUs, and it is clearly observable in the three OUs in the way the people work and accomplish their activities. It is the intrinsic motivation for quality improvement within every individuals and units that has empowered people within these three Asian OUs to move forward with QA implementation with strong commitment, inspired by their dedicated leaders. Shared responsibilities are the key words for an effective QA system. "Quality begins with the inner self" is the fundamental social capital for consistent QA implementation in these OUs.

Second, quality is a multidimensional concept, borrowing the term by Vlachopoulos (2016), as it embraces a broad range of products, services, deliveries and philosophies, and it attempts to meet the needs and expectations of students and different groups of stakeholders with differing interests. It means different things to different people (Harvey and Green, 1993). It is then the challenge of the OU leaders to empower all management and staff to 
address those conflicting interests and processes and ensure continuous quality improvement and enhancement of the OU system. Implementing a QA system implies challenging tasks of addressing multiple dimensions, aspects and meanings of quality from different perspectives and interests.

Third, QA is a systematic continuous improvement effort. QA as a system involves welldefined sets of principles, procedures and mechanisms organized to achieve the common goals of the institution. Effective QA system is supported with resources and tools needed for effective implementation by the people within the institutions. There seems to be no limit to continuous improvement, as the expectations of ODL leaders, staff, students and stakeholders will continue to increase from time to time. ODL institutions will carefully look at benchmark and good practices of others, and then develop systematic effort for continuous improvement and quality enhancement.

Fourth, QA implies effective mechanism and assessment, ensuring that different processes are carefully executed and assessed. The mechanism will define which processes to be conducted by whom using which resources. Effective QA system involves continuous quality assessment both internally and externally. Internal assessment is the foundation for continuous improvement, while external assessment goes further to serve as the external benchmark to ensure public credibility and meet the universally accepted good practices of ODL.

Fifth, QA is an attempt at exceeding the expectations of students and stakeholders. Good QA system is focused on customer satisfaction, and thus students and stakeholders will be the parties that most benefit from the QA effort. The expectations of students and stakeholders are dynamically changing to respond to professional competency requirements, societal needs and technological changes in the world of work. OU systems will continue to innovate to best serve the needs of their students and align themselves to the needs of employers and stakeholders for high caliber OU graduates.

Sixth, QA embraces a process of ODL transformation into online digital system and adaptability to disruption and the new ODL landscape. ODL system begins with the printbased correspondence system, moving to multimedia broadcast-based system, then to online digital system. These technological changes have been adopted by OUs, many of which have historically been established using the print-based platform. Modern OUs more recently founded during the digital age have naturally jumped into the digital online system, such as UPOU. And there are other OUs in the world that have transformed them gradually, and some of them more quickly to become digital online OUs. Both UT and AIOU particularly have been challenged to maintain and improve the quality of services to different groups of students with conflicting information technology literacies, one group being more technology literate than the other. Both OUs have gone through continuous balancing interests in adopting digital online system to serve their younger groups of students who are more digital literate and at the same time maintaining older groups of students who have restrictions on the use of online digital system. It is further complicated by the fact that there are diversities in terms of ease of access to online digital system due to geographic and infrastructure constraints.

The three Asian OUs under investigation, like many other OUs are constantly challenged to meet the expectations of their students and stakeholders through continuous improvement and quality enhancement. These OUs seem to have to work closely with their respective governments, other stakeholders and students to identify their needs and respond to their needs appropriately. QA is a highly dynamic process, and QA system is one of the instruments which can be effectively used to continuously improve and enhance the quality of ODL provisions.

To respond to the COVID-19 pandemic, the three OUs need to take necessary actions to ensure that their ODL services remain well implemented following quality guidelines. 
AAOUJ 15,3

\section{4}

Strategic plans and policy directions may have to be redrawn to accommodate such disruptions, and action plans need to carefully address the changing needs of the students and stakeholders. AIOU may have to speed up its plans to expand its online access and services to its students. For UT, its roadmap to be a leading cyber university may have to be revisited and materialized even sooner (Darojat et al., 2018), as online learning may have become the necessities of students in higher education in post-COVID-19. These efforts seem to be shared responsibilities among institutions, governments and relevant stakeholders.

Higher education institutions may have to rethink on their post-pandemic pedagogy (Murphy, 2020). The COVID-19 pandemic has challenged higher education system across the world to shift to online teaching and learning mode almost overnight, enforcing many reluctant institutions and educators to change their traditional pedagogical approach to online teaching and learning environment (Dhawan, 2020). A further study following the COVID-19 pandemic indicates that universities worldwide are moving faster towards online learning, and there seems to be stronger needs for the use and integration of technology enhanced learning into the system along with other needs for resources, staff readiness and student accessibility to technology (Ali, 2020). The post-COVID-19 necessitates higher education institutions to transform into technology-based teaching and learning that benefit learners, in which courses may be offered on fully online, hybrid or augmented immersive residential modes (Govindarajan and Srivastava, 2020). The world has been moving online fast, calling for higher education in digital age to move online (Zorn et al., 2018), and the post-COVID-19 experience may expediate this online digital transformation of higher education even faster.

Historically because of its departure from the face-to-face higher education system, the OU and ODL system has been established on careful quality considerations to ensure public trust and credibility. In terms of QA, the sudden disruption of COVID-19 poses specific challenges, as new policies, systems and procedures need to be adapted to meet the COVID-19 teaching and learning environment. The online component of ODL services may not be affected as much as the traditional ODL system requiring face-to-face services, such as the face-to-face learning support, paper-based examination and administrative services. Thus, online open university may continue its operations more smoothly than their traditional OU counterparts with face-to-to-face services. It remains to be seen how the landscape of higher education and online learning will continue to change for the long-term in the post-COVID-19 outbreak, and it is certain that QA remains at the forefront to ensure that the expectations of students and stakeholders can be exceeded. It will rest with individual institutions and the attitudes and integrity of the ODL human resources to continuously improve the quality ODL provision and the capability to adapt and effectively respond to disruptions such as the COVID-19 pandemic and further future challenges. The post-COVID-19 pandemic would have taught important lessons on the significant new roles of online learning and how to continuously improve them in the new landscape of online higher education.

\section{References}

AAOU (2019), “AAOU quality assurance framework”, available at: http://aaou.upou.edu.ph/qualityassurance-framework/ (accessed 5 March 2019).

Ahmad, I. (2018), "Indonesia good practices on quality assurance, recognition and student mobility programs", Presentation by Acting Director General of Learning and Student Affairs, Ministry of Research, Technology, and Higher Education, available at: https:/www.asem-education.org/ documents/senior-official-meetings-and-ministerial-meetings/isom-jakarta-2018/290-plenarysession-1-intan-ahmad/file (accessed 4 June 2018).

Al Tobi, A.S. and Duque, S. (2015), "Approaches to quality assurance and accreditation in higher education: a comparison between the Sultanate of Oman and the Philippines", Perspectives of Innovations, Economics and Business, Vol. 15 No. 1, pp. 41-48, doi: 10.15208/pieb.2015.03. 
Alfonso, G.J. (2015), “Quality assurance in distance education”, in Lumanta, M.F. (Ed.), Through Their Voices Through the Years Thought Papers of UPOU Chancellors, University of the Philippines Open University, Los Banos, pp. 126-130.

Ali, W. (2020), "Online and remote learning in higher education institutes: a necessity in light of COVID-19 pandemic", Higher Education Studies, Vol. 10 No. 3, pp. 16-25, doi: 10.5539/hes. v10n3p16.

Anderson, T. and Elloumi, F. (Eds) (2004), Theory and Practice of Online Learning, Athabasca University, Athabasca, available at: https://www.aupress.ca/books/120146-the-theory-andpractice-of-online-learning/.

Arinto, P.B. (2016), "Issues and challenges in open and distance e-learning: perspectives from the Philippines", International Review of Research in Open and Distance Learning, Vol. 17, doi: 10. 19173/irrodl.v17i2.1913.

ASEAN Secretariat (2016), ASEAN Guiding Principles for Quality Assurance and Recognition of Competency Certification Systems, ASEAN Secretariat, Jakarta, available at: https://asean.org/ storage/2012/05/ASEAN-Guiding-Principles-for-Quality-Assurance-and-Recognition-ofCompetency-Certification-Systems1.pdf.

AUN (ASEAN University Network) (2016), ASEAN University Network Quality Assurance: Guide to AUN-QA Assessment at Institutional Level, ASEAN University Network, Bangkok, available at: http://www.aunsec.org/pdf/Guide to AUN-QA Assessment at Programme Level Version 3 2015.pdf.

Batool, Z. and Qureshi, R.H. (2008), Quality Assurance Manual for Higher Education in Pakistan, Higher Education Commission Pakistan, Islamabad, available at: http://www.pieas.edu.pk/qec/ Quality-Assurance-Manual-for-Higher-Education-Pakistan.pdf.

Baturay, M.H. (2015), “An overview of the world of MOOCs”, Procedia - Social and Behavioral Sciences, Vol. 174, pp. 427-433, doi: 10.1016/j.sbspro.2015.01.685.

Belawati, T. and Nizam (Eds) (2020), Potret Pendidikan Tinggi di Masa Covid-19 (The Potrait of Higher Education during Covid-19), Direktorat Jenderal Pendidikan Tinggi, Jakarta, available at: http://repository.ut.ac.id/9010/.

Belawati, T. and Zuhairi, A. (2007), "The practice of a quality assurance system in open and distance learning: a case study at Universitas Terbuka Indonesia (The Indonesia Open University)", International Review of Research in Open and Distance Learning, Vol. 8 No. 1, pp. 1-15, available at: http://www.irrodl.org/index.php/irrodl/article/view/340/782.

Bibi, T., Rokhiyah, I. and Mutiara, D. (2018), "Comparative study of quality assurance practices in open distance learning (ODL) universities", International Journal of Distance Education and E-Learning (IJDEEL), Vol. 4 No. 1, pp. 26-39, doi: 10.36261/ijdeel.v4i1.478.

Brockerhoff, L., Huisman, J. and Laufer, M. (2015), Quality in Higher Education: A Literature Review, Centre for Higher Education Governance, Ghent University, Ghent, Belgium.

Chuah, P. and Lim, P. (2018), "Applying quality tools to improve student retention supporting process: a case study from WOU”, Asian Association of Open Universities Journal, Vol. 13 No. 1, pp. 60-72, doi: 10.1108/AAOUJ-01-2018-0003.

COL (2009), Quality Assurance Toolkit for Distance Higher Education Institutions and Programmes, Commonwealth of Learning Vancouver, BC, Canada, available at: http:/oasis.col.org/bitstream/ handle/11599/105/pub_HE_QA_Toolkit_web.pdf?sequence=1\&isAllowed=y.

Corpus, M.T. (2003), "Historical perspectives of the Philippine quality assurance system", Journal of Philippine Higher Education Quality Assurance, Vol. 1 No. 1, pp. 1-7, available at: http:// citeseerx.ist.psu.edu/viewdoc/download?doi=10.1.1.730.631\&rep=rep1\&type =pdf.

Darojat, O. (2018), "How are the results of quality assurance programs used to inform practices at a distance higher education?", The Turkish Online Journal of Distance Education, Vol. 19 No. 1, pp. 75-88, doi: 10.17718/tojde.382730. 
AAOUJ 15,3

\section{6}

Darojat, O., Huang, R.H., Liu, D.J., Tlili, A., Yang, J.F. and Wang, H.H. (2018), 34 Tahun Universitas Terbuka Cyber University Untuk Negeri (34 Years of Universitas Terbuka Cyber University for the Country), Universitas Terbuka, Tangerang, Selatan.

Dhawan, S. (2020), "Online learning: a panacea in the timeof COVID-19 crisis", Journal of Educational Technology Systems, pp. 1-18, doi: 10.1177/0047239520934018.

Dotong, C.I and Laguador, J.M. (2015), "Philippine quality assurance mechanisms in higher education towards internationalization", Studies in Social Sciences and Humanities, Vol. 3 No. 3, pp. 156-167, available at: https://research.lpubatangas.edu.ph/wp-content/uploads/2015/12/ SSSH-Philippine-Quality-Assurance-Mechanisms-in-Higher-Education.pdf.

Elken, M. and Stensaker, B. (2018), "Conceptualising 'quality work' in higher education”, Quality in Higher Education, Vol. 24 No. 3, pp. 189-202, doi: 10.1080/13538322.2018.1554782.

Govindarajan, V. and Srivastava, A. (2020), "A post pandemic strategy for US higher education", Harvard Business Review Change Management, available at: https://hbr.org/2020/06/a-postpandemic-strategy-for-u-s-higher-ed.

Grifoll, J., Huertas, E., Prades, A., Rodríguez, S., Rubin, Y., Mulder, F. and Ossiannilsson, E. (2010), "Quality assurance of e-learning", ENQA Workshop Report (14), available at: http://www.enqa. eu/indirme/papers-andreports/workshop-and-seminar/ENQA_wr_14.pdf.

Harvey, L. and Green, D. (1993), "Defining quality", Assessment and Evaluation in Higher Education, Vol. 18 No. 1, pp. 9-34. doi: 10.1080/0260293930180102.

Harvey, L., Green, D. and Burrows, A. (1993), "Assessing quality in higher education: a trans binary research project", Assessment and Evaluation in Higher Education, Vol. 18 No. 2, pp. 143-148. doi: $10.1080 / 0260293930180206$.

Hénard, F. and Roseveare, D. (2012), Fostering Quality Teaching in Higher Education: Policies and Practices an IMHE Guide for Higher Education Institutions, OECD, Paris, available at: https:// www.oecd.org/education/imhe/QT policies and practices.pdf.

Huang, R.H., Liu, D.J., Guo, J., Yang, J.F., Zhao, J.H., Wei, X.F., Knyazeva, S., Li, M., Zhuang, R.X., Looi, C.K. and Chang, T.W. (2020a), Guidance on Flexible Learning during Campus Closures: Ensuring Course Quality of Higher Education in COVID-19 Outbreak, Smart Learning Institute of Beijing Normal University, Beijing, available at: https://iite.unesco.org/publications/guidance-onflexible-learning-during-campus-closures-ensuring-course-quality-of-higher-education-in-covid19-outbreak/.

Huang, R.H., Liu, D.J., Tlili, A., Yang, J.F. and Wang, H.H. (2020b), Handbook on Facilitating Flexible Learning during Educational Disruption: The Chinese Experience in Maintaining Undisrupted Learning in COVID-19 Outbreak, Smart Learning Institute of Beijing Normal University, Beijing, available at: https://iite.unesco.org/publications/handbook-on-facilitating-flexiblelearning-during-educational-disruption/.

Huertas, E., Biscan, I., Ejsing, C., Kerber, L., Kozlowska, L., Ortega, S.M., Lauri, L., Risse, M., Schörg, K. and Seppmann, G. (2018), Considerations for Quality Assurance of Learning Provision Report from the ENQA Working Group VIII on Quality Assurance and Learning Occasional Papers 26, European Association for QA in Higher Education AISBL, Brussels, Belgium, available at: https://enqa.eu/indirme/Considerations for QA of e-learning provision.pdf.

IAU (2020), "The impact of COVID-19 on higher education worldwideResources for higher education institutions resources for higher education institutions", available at: https://www.iau-aiu.net/ IMG/pdf/covid-19_and_he_resources.pdf.

Inglis, A. (2005), "Quality improvement, quality assurance, and benchmarking: comparing two frameworks for managing quality processes in open and distance learning", International Review of Research in Open and Distance Learning, Vol. 6 No. 1, doi: 10.19173/irrodl.v6i1.221.

Iqbal, M.J. and Ahmad, M. (2010), "Enhancing quality of education through E-learning: the case study of Allama iqbal open university", Turkish Online Journal of Distance Education-TOJDE, Vol. 11 No. 1, pp. 84-97, available at: http://tojde.anadolu.edu.tr/makale_goster.php?id=556. 
Jamandre, N.K.F. (2011), "Quality assurance in distance education achieved in the Philippines", Asian Journal of Distance Education, Vol. 9 No. 1, pp. 90-97, available at: https://www.asianjde.org/ojs/ index.php/AsianJDE/article/view/173.

Jung, I. (2012), “Asian learners' perception of quality in distance education and gender differences", International Review of Research in Open and Distance Learning, Vol. 13 No. 2, pp. 1-25, doi: 10. 19173/irrodl.v13i2.1159.

Jung, I., Wong, T.M., Li, C., Baigaltugs, S. and Belawati, T. (2011), "Quality assurance in Asian distance education: diverse approaches and common culture", International Review of Research in Open and Distance Learning, Vol. 12 No. 6, pp. 63-83, doi: 10.19173/irrodl.v12i6.991.

Jung, I., Wong, T.M. and Belawati, T. (Eds) (2013), Quality Assurance in Distance Education and E-Learning Challenges and Solutions from Asia, Sage Publications, New Delhi and IDRC, Ottawa.

Kemenistekdikti (Ministry of Research, Technology, and Higher Education (2018), Pedoman Sistem Penjaminan Mutu Internal Pendidikan Akademik - Pendidikan Vokasi - Pendidikan Profesi Pendidikan Jarak Jauh (Guidelines for Internal QA System: Academic Education - Vocational Education - Professional Education - Distance Education), Kemenristekdikti (Ministry of Research, Technology, and Higher Education), Jakarta, available at: http://spmi.ristekdikti.go. id/uploads/publications/Buku Pedoman 0SPMI 2018.pdf.

Kennepohl, D. and Shaw, L. (2010), Teaching Science Online and at a Distance, Athabasca University, Edmonton, available at: https://www.aupress.ca/app/uploads/120162_99Z_Kennepohl_Shaw_ 2010-Accessible_Elements.pdf.

Kooi, L.T. and Ping, T.A. (2012), "Assuring the quality of online teaching and learning: the case of Wawasan Open University", Asian Association of Open Universities Journal, Vol. 7 No. 1, pp. 13-33, doi: 10.1108/AAOUJ-07-01-2012-B002.

Llaneta, C.A.C. (2019), "Plans, Possibilities and Progress: UP academics moving into the "next normal”, available at: https://www.up.edu.ph/plans-possibilities-and-progress-up-academicsmoving-into-thenext-normal/ (accessed 31 August 2020).

Logli, C. (2016), "Higher education in Indonesia: contemporary challenges in governance, access, and Quality", in Neubauer, D., Hawkins, J., Lee, M. and Collins, C. (Eds), Handbook of Asian Higher Education, Palgrave Macmillan, New York City, NY, pp. 561-581.

Marciniak, R. (2018), "Quality assurance for online higher education programmes: design and validation of an integrative assessment model applicable to Spanish universities", International Review of Research in Open and Distributed Learning, Vol. 19 No. 2, pp. 126-154, available at: http://www.irrodl.org/index.php/irrodl/article/view/3443/4622.

Mir, K. (2017), "Design and development of online student support system", Pakistan Journal of Distance and Online Learning, Vol. 3 No. 1, pp. 1-8.

Mir, K., Iqbal, M.Z. and Shams, J.A. (2019), “An investigation of AIOU students' satisfaction about formative m-assessment using SMS technology", Pakistan Journal of Distance and Online Learning, Vol. 5 No. 2, pp. 157-174.

Murphy, M.P.A. (2020), "COVID-19 and emergency eLearning: consequences of the securitization of higher education for post-pandemic pedagogy", Contemporary Security Policy, Vol. 41 No. 3, pp. 492-505. doi: 10.1080/13523260.2020.1761749.

Nizam (2020), "Potret transformasi digital: mendadak daring (The portrait of digital transformation: suddenly going into the networked learning)", in Belawati, T. and Nizam (Eds), Potret Pendidikan Tinggi di Masa Covid-19 (The Potrait of Higher Education in the Covid-19 Era), DirektoratJenderal Pendidikan Tinggi Kementerian Pendidikan dan Kebudayaan, Jakarta, pp. 31-44, available at: http://repository.ut.ac.id/9010/.

OECD (2020), "Supporting the continuation of teaching and learning during the COVID-19 Pandemic", available at: https://www.oecd.org/education/Supporting-the-continuation-of-teaching-andlearning-during-the-COVID-19-pandemic.pdf. 
AAOUJ 15,3
Oruga, M.D. and Bagos, J.R. (2018), “Applying the e-learning framework: evaluating an e-learning course toward the improvement of quality of ODeL programs", The International Journal on Open and Distance e-Learning (IJODeL), Vol. 4 No. 1, pp. 33-43, available at: http://ijodel.com/ wp-content/uploads/2018/10/003_Oruga_Bagos.pdf.

Ruiz, A.J. and Junio-Sabio, C. (2012), "Quality assurance in higher education in the Philippines", Asian Journal of Distance Education, Vol. 10 No. 2, pp. 63-70, available at: http://www.asianjde.org/ojs/ index.php/AsianJDE/article/view/210.

Ryan, P. (2015), "Quality assurance in higher education: a review of literature”, Higher Learning Research Communications, Vol. 5 No. 4, doi: 10.18870/hlrc.v5i4.257.

Schindler, L., Puls-Elvidge, S., Welzant, H. and Crawford, L. (2015), "Definitions of quality in higher education: a synthesis of the literature", Higher Learning Research Communications, Vol. 5 No. 3, pp. 3-13, doi: 10.18870/hlrc.v5i3.244.

Sembiring, M.G. and Rahayu, G. (2019), "Verifying the moderating role of satisfaction on service quality and students' accomplishment in ODL perspective", Asian Association of Open Universities Journal, Vol. 15 No. 1, pp. 1-12, doi: 10.1108/AAOUJ-08-2019-0035.

Stella, A. and Gnanam, A. (2004), "Quality assurance in distance education: the challenges to be addressed”, Higher Education, Vol. 47, pp. 143-160, 2004, doi: 10.1023/B:HIGH.0000016420. $17251.5 \mathrm{c}$.

Stensaker, B. (2018), "Quality assurance and the battle for legitimacy - discourses, disputes and dependencies”, Higher Education Evaluation and Development, Vol. 12 No. 2, pp. 54-62, doi: 10. 1108/HEED-10-2018-0024.

Tadjudin, M.K. (2001), "Establishing a QA system in Indonesia”, International Higher Education, Vol. 25, pp. 16-18.

UNESCO (2020a), COVID-19 and Higher Education: Today and Tomorrow Impact Analysis, Policy Responses and Recommendations, UNESCO, Paris, available at: http:/www.iesalc.unesco.org/ en/wp-content/uploads/2020/05/COVID-19-EN-130520.pdf.

UNESCO (2020b), Education in a Post-COVID World: Nine Ideas for Public Action International Commission on the Futures of Education, UNESCO, Paris, available at: https://unesdoc.unesco. org/ark:/48223/pf0000373717/PDF/373717eng.pdf.multi.

University of the Philippines (2020), "University History Emerging excellence: UP in the past 112 years”, available at: https://www.up.edu.ph/about-up/university-history/ (accessed 31 August 2020).

Usmani, M.A.W. and Khatoon, S. (2016), "Impact of quality assurance initiative on Pakistani Universities", International Journal of Research Studies in Education, Vol. 5 No. 4, pp. 83-90, available at: http:// consortiacademia.org/wp-content/uploads/IJRSE/IJRSE_v5i4/1326-4696-1-PB.pdf.

Usmani, M.A.W., Khatoon, S., Shammot, M.M. and Zamil, A.M. (2012), "Towards a Network of quality assurance in HigherEducation: a Pakistani model”, Archives Des Sciences, Vol. 65 No. 7, pp. 224-229, available at: https:/www.semanticscholar.org/paper/Towards-a-Network-ofQuality-Assurance-in-Higher-A-Usmani-Khatoon/03ae54341ff5d45a4464432fb72464df 28a61081?citationIntent $=$ methodology\#citing-papers

UT (2019a), Laporan Kerja Tahunan Rektor Universitas Terbuka 2018 (Annual Report Rector of Universitas Terbuka 2018), Universitas Terbuka, Tangerang Selatan.

UT (2020), Laporan Kerja Tahunan Rektor Universitas Terbuka 2019 (Annual Report Rector of Universitas Terbuka 2019), Universitas Terbuka, Tangerang Selatan.

Uvalić-Trumbić, S. and Daniel, S.J. (2013), A Guide to Quality in Online Learning, Academic Partnerships, Mountainview, California, available at: https:/www.academicpartnerships.com/ Resource/documents/A-Guide-to-Quality-in-Online-Learning.pdf (accessed 11 August 2020).

Van Kemenade, E., Pupius, M. and Hardjono, T.W. (2008), "More value to defining quality”, Quality in Higher Education, Vol. 14 No. 2, pp. 175-185, doi: 10.1080/13538320802278461. 
Vlachopoulos, D. (2016), "Assuring quality in e-learning course design: the roadmap", International Review of Research in Open and Distance Learning, Vol. 17 No. 6, doi: 10.19173/irrodl.v17i6.2784.

Volungeviciene, A., Tereseviciene, M. and Tait, A.W. (2014), "Framework of quality assurance of TEL integration into an educational organization", International Review of Research in Open and Distance Learning, Vol. 15 No. 6, doi: 10.19173/irrodl.v15i6.1927.

World Bank (2020), "Remote learning, distance education and online learning during the COVID19 pandemic: a Resource List by the World Bank's EdTech Team”, available at: https:// openknowledge.worldbank.org/handle/10986/33499.

World Bank (2020a), "The COVID-19 crisis response: supporting tertiary education for continuity, adaptation, and innovation", available at: http://pubdocs.worldbank.org/en/808621586532 673333/WB-Tertiary-Ed-and-Covid-19-Crisis-for-public-use-April-9-FINAL.pdf.

Zhang, W. and Cheng, Y.L. (2012), "Quality assurance in learning: PDPP evaluation model and its application”, The International Review of Research in Open and Distance Learning, Vol. 13 No. 3, pp. 66-82, available at: http://www.irrodl.org/index.php/irrodl/article/view/1181/2241.

Zhang, J. and Patil, J. (2017), "Who guarantees the quality of the quality assurance agencies? The exploration of the establishment and growth of the Asia-Pacific Quality Register (APQR)", Higher Education Evaluation and Development, Vol. 11 No. 2, pp. 58-67, doi: 10.1108/HEED-072017-0001.

Zorn, A., Haywood, J. and Glachant, J.M. (Eds) (2018), Higher Education in the Digital Age Moving Academia Online, Edward Elgar Publishing, Cheltenham and Northampton, MA.

Zuhairi, A. (2019), "The operational aspects of open and distance learning and its quality assurance system in Universitas Terbuka", Jurnal Pendidikan Terbuka dan Jarak Jauh, Vol. 20 No. 2, pp. 74-89, doi: 10.33830/ptjj.v20i2.122.2019.

Zuhairi, A., Karthikeyan, N. and Priyadarshana, S.T. (2019), "Supporting students to succeed in open and distance learning in the Open University of Sri Lanka and Universitas Terbuka Indonesia", Asian Association of Open Universities Journal, Vol. 15 No. 1, pp. 13-35, doi: 10.1108/AAOUJ-092019-0038.

Zuhairi, A., Hsueh, A.C.T. and Chiang, I.C.N. (2020), "Empowering lifelong learning through open universities in Taiwan and Indonesia", Asian Association of Open Universities Journal, ahead-ofprint No. ahead-of-print, doi: 10.1108/AAOUJ-12-2019-0059. 


\section{AAOUJ 15,3 \\ Appendix \\ List of people consulted through focus group discussion and interviews at UPOU Philippines}

\begin{tabular}{ll}
\hline Name & Responsibility \\
\hline Dr. Melinda F. Lumanta & Vice Chancellor for Academic Affairs \\
Dr. Jean A. Saludadez & Vice Chancellor for Finance and Administration \\
Dr. Ricardo T. Bagarino & Dean, Faculty of Education \\
Dr. Aurora V. Lacaste & Assistant Professor and Registrar \\
Dr. Maria Rowena Raymundo & Assistant Professor, Chair of Master of Distance Education Program and \\
& Quality Assurance \\
Dr. Ria Mae Borromeo & Assistant Professor, Faculty of Information and Communication Studies \\
Mr. Michael P. Lagaya & Assistant to the Vice President for Administration \\
Ms. Anna Ma. Elizabeth F. Cañas- & Information Officer \\
Llamas & \\
Ms. Ammanessi Joy Lapitan & QA Research Assistant, Office of Vice Chancellor Academic Affairs \\
Ms. Ivy Rosemarie Ortiguero & \\
Ms. Jessica Maurene Tapia & \\
Ms. Shielo Pasahol & \\
\hline
\end{tabular}

\section{Corresponding author}

Aminudin Zuhairi can be contacted at: aminz@ecampus.ut.ac.id

For instructions on how to order reprints of this article, please visit our website:

www.emeraldgrouppublishing.com/licensing/reprints.htm

Or contact us for further details: permissions@emeraldinsight.com 